\title{
The QSAR study for antibacterial activity of structurally diverse nitroaromatics
}

\author{
Jonas Šarlauskas ${ }^{\star}$, \\ Evelina Polmickaitè-Smirnova, \\ Narimantas Čènas, \\ Kastis Krikštopaitis, \\ Žilvinas Anusevičius* \\ Institute of Biochemistry, \\ Life Sciences Center, \\ Vilnius University, \\ Sauletekio Ave. 7 , \\ 10257 Vilnius, Lithuania
}

\begin{abstract}
The antibacterial activity of a series of structurally diverse nitroaromatic compounds (NACs) (nitrobenzene and nitroheterocyclic derivatives) was estimated in terms of the minimum inhibitory concentrations (MICs) against Gram-positive Staphylococcus aureus and Gram-negative Escherichia coli bacteria strains in vitro. The resultant log of 1/MICs (pMICs) was subjected to a quantitative structure-activity relationship analysis (QSAR) using a set of molecular descriptors of the compounds assessed by means of quantum mechanical computation and other methods. The estimated pMIC values of NACs tentatively increased with an increase in their electrophilic potency (in terms of LUMO energy) along with the LUMO-HOMO energy gap (or chemical hardness) towards both bacteria strains. No reliable contribution of lipophilicity (octanol/water log P) of nitroaromatics was found to both bacteria strains. The activity of NACs towards $S$. aureus increased with an increase in their molecular weight and van der Waals volume, and it also tended to increase with an increase in their polar surface area (PSA) and in the number of hydrogen bond-acceptors (HBAs), whereas using these descriptors against $E$. coli strain, no satisfactory correlations were obtained. The activity of NACs towards both bacteria strains showed a parabolic type dependence upon the highest positive values of molecular electrostatic potentials $\left(V_{S, \max }\right)$ that might partially be associated with the non-specific interaction of nitroaromatics with the surfaces of the negatively charged envelopes of bacteria at the initial stage of NACs' action.
\end{abstract}

Keywords: nitroaromatic compounds, antibacterial activity, QSAR, quantum mechanical computation, DFT

\section{INTRODUCTION}

Nitroaromatic compounds (NACs) represent one of the largest groups of industrial chemicals used for production of a wide spectrum of products, including dyes, plastics, polymers, high energy materials (explosives and propellants), pesticides,

\footnotetext{
*Corresponding author. Email: jonas.sarlauskas@ bchi.vu.lt; zilvinas.anusevicius@bchi.vu.lt
}

and many other industrial compounds. In addition, they are widely applied as pharmaceuticals, antimicrobial agents or food additives ([1-4], and refs. therein).

Amongst the multiple mechanisms of (cyto) toxic and/or therapeutic action of NACs, their electrophilic reactivity is widely agreed to be one of the most important determinants. The primary steps of their reductive conversion involve 
the sequential single- and/or two-electron reduction of nitro group(s) via the formation of nitroradical, nitroso and hydroxylamine intermediates. The single-electron reduction of NACs to nitroanion radicals is rapidly back-oxidized by molecular oxygen concomitantly generating superoxide along with other reactive oxygen species (ROS) such as peroxide and hydroxyl radicals causing damage to the cell components ([3], 4h, and refs. therein). This reaction has frequently been defined to be mediated by single-electron transferring flavoenzymes, such as, for instance, mammalian NADPH: cytochrome P-450 reductase, NADH: ubiquinone reductase or bacterial oxygen-sensitive (Type II) nitroreductases as found in Escherichia coli strains ([5, 6], and refs. therein). The two(four)-electron reduction of nitroaromatics, catalyzed by two-electron transferring flavoenzymes, such as mammalian NAD $(\mathrm{P})$ $\mathrm{H}$ : quinone reductase (DT-diaphorase, NQO1) or xanthine oxidase, leads to generation of highly reactive nitroso and hydroxylamine intermediates giving rise to the formation of their alkylating products with nucleic acids and proteins [7-9]. The bacterial oxygen-insensitive (Type I) nitroreductases also mediate these reactions ([6, 10], and refs. therein).

The (cyto)toxicity of nitroaromatics against mammalian cells was often observed to increase with an increase in their electron-accepting potency (expressed in terms of the experimentally measured single-electron reduction potentials $\left(\mathrm{E}_{7}^{1}\right)$ or quantum mechanically assessed electrophilic potencies) which implied that the reductive activation of the compounds may be one of the ascendant mechanisms of their action ([11-13, and refs. therein). Many quantitative structure activity relationship (QSAR) studies emphasized the importance of lipophilic properties of NACs which correlated with toxic effects of the compounds as an additional descriptor on their electrophilic potency ([13], and refs. therein). Many efforts have been made to model accute toxicity of NACs applying a set of molecular descriptors, such as the energies of the highest occupied $\left(\mathrm{E}_{\mathrm{HO}}\right.$ $\left.{ }_{\mathrm{MO}}\right)$ and the lowest unoccupied $\left(\mathrm{E}_{\mathrm{LUMO}}\right)$ molecular orbitals, the LUMO-HOMO energy gap $\left(\Delta \mathrm{E}_{\mathrm{H}-\mathrm{L}}\right)$ (or chemical hardness, $\eta=\mathrm{E}_{\text {LUMO }}-\mathrm{E}_{\text {HOMO }}$, or softness, $S=1 / \eta$ ), vertical and/or adiabatic ionization potentials (IPs) and electron affinities (EAs), electro- static densities, charges and potentials, molecular area and/or volume, (topological) polar surface area ((T)PSA), the numbers of hydrogen-bond donor (HBD) or hydrogen-bond acceptor (HBA), lipophilicity $(\log \mathrm{P}$ and/or $\log \mathrm{D})$, a set of topological indices, etc. [13-17]. In addition, the efforts have been made to explore the DFT-based reactivity indices of nitroaromatics for prediction of their toxicity, viz., the chemical hardness ( $\eta$ ), the chemical potential $(\mu)$ (or electronegativity, $\chi=-\mu)$ and the electrophilicity $(\omega)$ ([18], and refs. therein). The electrophilic potency (in terms of $\left.\mathrm{E}_{\mathrm{LUMO}}\right)$ along with the lipophilic and steric factors of NACs were found to be important determinants of toxic effects of the compounds on bacteria strains such as Salmonella typhimurium [19, 20].

In the present work, the activity of a series of the diverse structure nitroaromatics, viz., nitrobenzene and nitrogen-containing nitroaromatic compounds was assessed against Gram-positive (Staphylococcus aureus ATCC 25923) and Gramnegative (Escherichia coli ATCC 25922) bacteria strains in vitro and the QSAR studies were performed in an attempt to define possible links between the toxic activity of nitroaromatics and their molecular descriptors obtained by means of quantum mechanical computation.

\section{EXPERIMENTAL}

Chemicals and bacteria strains. The model nitroaromatics (viz., nitrobenzene, 4-nitrobenzyl alcohol, 4-nitroacetophenone, 4-nitrobenzaldehyde, 1,2-, 1,3- and 1,4-dinitrobenzenes) were obtained from Sigma-Adrich and used without further purification. 2,4,6-Trinitrophenyl-N-methyl-nitramine (tetryl) was obtained following the method [21]. The N-containing heterocyclic nitrocompounds 3,6-dinitro-9H-carbazole (DNC), 1,3,6,8-tetranitro-9H-carbazole (TNC), 4,5,6-trinitrobenzimidazol-2-one (TriNBO) and 4,5,6,7-tetranitrobenzimidazol-2-one (TNBO) were synthesized according to methods [22-25], 3-nitro-1,2,4-triazole and 4(5)-nitroimidazole compounds were obtained as described in [26-27]. Their purities and structures were verified by means of the melting points, and TLC, NMR and IR analysis.

The Gram-negative Escherichia coli (ATCC 25922) and Gram-positive Staphylococcus aureus 
(ATCC 25923) bacteria strains were obtained from the American Type Culture Collection (ATCC, Manassas, VA, USA).

Viability testing. The antibacterial activity of NACs was measured in accordance with the method as described in [28]. The stock solutions of the examined compounds were prepared in dimethylsulfoxide (DMSO). For each bacteria isolate, three to five colonies of the same morphological appearance from the fresh agar dish were selected, transferred to the tube containing $20 \mathrm{ml}$ of a Mueller-Hinton growth medium (Sigma-Aldrich, USA) and incubated at $37^{\circ} \mathrm{C}$ in a shaker (225 r.p.m.) until bacteria optical density at $600 \mathrm{~nm}\left(\mathrm{OD}_{600}\right)$ reached $\sim 0.4$ optical unit $\left(\sim 2 \times 10^{8}\right.$ cells per $\left.\mathrm{mL}\right)$. For each agar dish, $20 \mathrm{~mL}$ agar (at $\sim 50^{\circ} \mathrm{C}$ ) was added to the container, infused geometrically increasing concentrations (a two-fold dilution series) of NACs, mixed well and poured into a Petri dish. A control agar dish without any substance was also used. The percentage of DMSO added to the agar dish did not exceed $2 \%(\mathrm{v} / \mathrm{v})$. The bacterial suspensions were mixed, adjusted to $10^{8} \mathrm{cfu} \mathrm{mL}^{-1}$ by vortexing and diluted 1:10. The final inoculum for the spot was adjusted up to the desired cell density $\left(\sim 10^{4} \mathrm{cfu}\right.$ per spot). The agar plates were incubated at $37^{\circ} \mathrm{C}$ for $16 \mathrm{~h}$ and the minimal inhibitory concentration (MIC) was read. All assays were carried out at least in triplicates for each concentration of NACs.

Computational details and statistical analysis. The quantum mechanical computations of nitroaromatics used in this work were performed using the Spartan 10' software package (Wavefunction Inc., Version 1.1.0). Their structures were initially refined by the Merck Molecular Force Field (MMFF) method, and further optimization was conducted by the semi-empirical PM6 method followed by the restricted Hartree Fock (RHF) method with the 6-31 G (d, p) basis set. The final optimization and assessment of the electronic and structural parameters of the compounds were performed applying the B3LYP functional method in conjunction with the CC-PVDZ basis set. At each computational stage, the structures of the compounds were globally optimized without symmetry restrictions, and their stationary points were verified by the normal mode analysis which yielded no imaginary frequencies, implying that their structures correspond to a local minimum of a potential energy surface.
The molecular electrostatic potentials (MEPs) of the compounds used in this work were obtained at the RB3LYP/CC-PVDZ level by taking the surface of the contours of the electron density $\left(\rho(r)=0.001\right.$ a.u. (electrons/bohr $\left.\left.{ }^{3}\right)\right)$ [29, 30] encompassing $98-99 \%$ of the total electronic charge. The values of the logarithm of the octanol/water partition coefficient $\left(\log \mathrm{P}_{\text {oct }}\right)$ were calculated by using the ACD/Labs package (Version C10E41, Build76694, Toronto, Canada).

The multiple regression and statistical analysis were performed using the SigmaPlot 2000 (SPSS Inc., Version 6.10) and Statistica (StatSoft Inc., Version 8.0) packages.

\section{RESULTS AND DISCUSSION}

Table 1 provides a set of the calculated descriptors of nitroaromatics used in the QSAR approach to define the links with their biological activity:

(A) The energies of the lowest unoccupied molecular orbital $\left(\mathrm{E}_{\mathrm{LUMO}}\right)$ and the highest occupied molecular orbital $\left(\mathrm{E}_{\text {номо }}\right)$, characterizing the electrophilic/electron-accepting and nucleophilic/ electron-donating potencies of the compounds, respectively, which could be approximated to the electron affinity $\left(\mathrm{EA}=-\mathrm{E}_{\mathrm{LUMO}}\right)$ and the ionization potential $\left(\mathrm{IP}=-\mathrm{E}_{\text {номо }}\right)$. Note that $\mathrm{E}_{\text {LUMO }}$ values of nitroaromatics have previously been observed to correlate well with single-electron reduction potentials as well as electrochemical peak potentials of the compounds [31, 32];

(B) The LUMO-HOMO energy gap $\left(\Delta \mathrm{E}_{\mathrm{H}-\mathrm{L}}\right)$ or chemical hardness $\left(\eta=\mathrm{E}_{\text {LUMO }}-\mathrm{E}_{\text {Hомо }}\right)$ or softness $(S=1 / \eta)$ of the compounds, which may serve as a rough criterion of their thermodynamic stability and reactivity ([33, 34], and refs. therein);

(C) The structural and other descriptors of molecules used for prediction of their permeability, viz., the molecular weight (MW), the van der Waals volume (vdWvol), the lipophilicity (octanol/water partition coefficient, $\log \mathrm{P}$ ), the polar surface area (PSA), the number of hydrogen bond-donors (HBDs) and hydrogen-bond acceptors (HBAs) ([35], and refs. therein).

In addition, Table 1 provides the molecular electrostatic potentials (MEPs) of nitroaromatics, i.e. the highest (positive) potentials around the hydrogen atoms $\left(V_{S, \max }\right)$ and the lowest (negative) potentials $\left(V_{S, \min }\right)$ over the oxygen atoms of nitro 
Table 1. The calculated molecular descriptors of NACs: the energy of the lowest molecular orbital $\left(\mathrm{E}_{\mathrm{Lumo}}\right)$, the energy of the highest occupied molecular orbital $\left(\mathrm{E}_{\text {номо }}\right)$, the LUMO-HOMO energy gap $\left(\Delta \mathrm{E}_{\mathrm{LH}}\right)$, the molecular weight (MW) and van der Walls volume (vdW), the 1-octanol/water partition coefficient (log P), the polar surface area (PSA), the hydrogen bond-donor (HBD) and acceptor (HBA) counts, the most positive $\left(V_{s, \max }\right)$ and the most negative $\left(V_{s, \min }\right)$ electrostatic potentials of the molecular surface

\begin{tabular}{|c|c|c|c|c|c|c|c|c|c|c|}
\hline \multirow{2}{*}{ No. } & \multirow{2}{*}{ Compound } & $\mathbf{E}_{\text {LUMO }}$ & $\mathbf{E}_{\text {номо }}$ & \multirow{2}{*}{$\Delta \mathrm{E}_{\mathrm{L}-\mathrm{H}}$} & \multirow{2}{*}{ MW } & \multirow{2}{*}{$\frac{\mathrm{vdW}}{\AA^{3}}$} & \multirow{2}{*}{$\log P$} & \multirow{2}{*}{$\frac{\text { PSA }}{\AA^{2}}$} & \multirow{2}{*}{$\begin{array}{l}\text { HBD/ } \\
\text { HBA }\end{array}$} & \multirow{2}{*}{$\frac{V_{s, \max } / V_{s, \min }}{\mathrm{kJ} / \mathrm{mol}}$} \\
\hline & & \multicolumn{2}{|c|}{ eV } & & & & & & & \\
\hline 1 & 1,3,5,8-Tetranitro-9H-carbazole & -3.58 & -7.79 & 4.21 & 347.2 & 269.0 & 2.52 & 161.0 & $1 / 13$ & $187 /-114$ \\
\hline 2 & $\begin{array}{l}\text { 2,4,6-Trinitrophenyl-N-methyl- } \\
\text { nitramine }\end{array}$ & -3.92 & -8.21 & 4.29 & 287.1 & 216.5 & 1.49 & 152.3 & $0 / 13$ & 184/-116 \\
\hline 3 & 3,6-Dinitro-9H-carbazole & -2.56 & -6.84 & 4.28 & 257.2 & 226.9 & 3.18 & 89.6 & $1 / 7$ & $297 /-154$ \\
\hline 4 & 4,5,6-TriNBO & -3.51 & -7.39 & 3.88 & 269.1 & 196.9 & 2.25 & 147.7 & 2/12 & $313 /-134$ \\
\hline 5 & 4,5,6,7-TNBO & -4.30 & -7.77 & 3.47 & 314.1 & 218.6 & 2.28 & 184.2 & $2 / 15$ & $277 /-109$ \\
\hline 6 & 2,4,6-Trinitrotoluene & -3.46 & -8.45 & 4.99 & 227.1 & 181.6 & 1.68 & 113.6 & $0 / 9$ & $166 /-108$ \\
\hline 7 & 3,4-Dinitrotoluene & -2.89 & -7.70 & 4.81 & 182.1 & 160.9 & 1.84 & 75.9 & $0 / 6$ & $143 /-142$ \\
\hline 8 & 1,4-Dinitrobenzene & -3.48 & -8.40 & 4.92 & 168.1 & 142.5 & 1.37 & 77.7 & $0 / 6$ & $106 /-107$ \\
\hline 9 & 1,2-Dinitrobenzene & -3.14 & -8.46 & 5.32 & 168.1 & 142.5 & 1.84 & 77.7 & $0 / 6$ & $123 /-126$ \\
\hline 10 & 2-Nitrobenzonitrile & -3.09 & -8.00 & 4.91 & 148.1 & 139.9 & 1.54 & 52.2 & $0 / 4$ & $122 /-157$ \\
\hline 11 & 4-Nitrobenzonitrile & -3.20 & -8.16 & 4.96 & 161.9 & 140.6 & 1.19 & 54.2 & $0 / 4$ & $112 /-133$ \\
\hline 12 & 4-Nitrobenzaldehyde & -3.15 & -7.61 & 4.46 & 151.1 & 142.0 & 1.56 & 53.5 & $0 / 4$ & $114 /-120$ \\
\hline 13 & 1,3-Dinitrobenzene & -3.14 & -8.46 & 5.32 & 168.1 & 142.5 & 1.62 & 77.7 & $0 / 6$ & $123 /-112$ \\
\hline 14 & 4-Nitroacetophenone & -2.97 & -7.38 & 4.41 & 165.2 & 160.1 & 1.42 & 53.1 & $0 / 4$ & $118 /-130$ \\
\hline 15 & 4-Nitrobenzyl alcohol & -2.44 & -7.51 & 5.07 & 153.1 & 146.8 & 0.76 & 58.5 & $1 / 4$ & $245 /-130$ \\
\hline 16 & Nitrobenzene & -2.47 & -7.70 & 5.32 & 123.1 & 121.0 & 1.95 & 38.9 & $0 / 3$ & $90 /-138$ \\
\hline 17 & 3-Nitro-1,2,4-triazole & -3.15 & -7.61 & 4.46 & 151.1 & 142.0 & -0.41 & 53.5 & $0 / 4$ & 264/-165 \\
\hline 18 & 4(5)-Nitro-imidazole & -2.54 & -7.32 & 4.78 & 113.1 & 95.8 & 0.35 & 59.9 & $1 / 5$ & $225 /-133$ \\
\hline
\end{tabular}

groups. MEPs have been shown to be suitable for prediction of non-covalent (largely electrostatic) interaction of molecules [36-40].

Table 2 comprises the results in vitro of the antibacterial activity of NACs, represented in terms of the minimum inhibitory concentration (MIC) along with the log of $1 / \mathrm{MIC}$ values (pMICs). The compounds showed activity with MICs ranging from $1.0 \mu \mathrm{g} / \mathrm{mL}(2.9 \mu \mathrm{M})$ for tetranitrocarbazole (TNC) against $S$. aureus to $1024 \mu \mathrm{g} / \mathrm{mL}$ (4.4 mM) for nitrobenzene against both bacteria strains. The activity of NACs (in terms of pMICs) tentatively increased with an increase in their electrophilic/electron-accepting potency (expressed in terms of the negative $\mathrm{E}_{\mathrm{LUMO}}$ values) against $S$. aureus $(R=0.64, F=10.74)$, and a higher regression was defined excluding TNBO compound (5) (Eq. (1); $R=0.710, F=14.70$ ); meanwhile, for the activity of NACs versus $\mathrm{E}_{\text {LUMO }}$ against $E$. coli, valid regression was obtained (Eq. (2); $R=0.72, F=7.10$ ) excluding NBO de- rivatives (4 and 5) which showed a markedly lower activity compared with their electrophilic potency:

$$
\begin{aligned}
& \mathrm{pMIC}=-6.85( \pm 0.93)-1.36( \pm 0.29) \mathrm{E}_{\mathrm{LUMO}}, \\
& \mathrm{pMIC}=-6.38( \pm 0.99)-1.26( \pm 0.31) \mathrm{E}_{\mathrm{LUMO}} .
\end{aligned}
$$

A satisfactory regression was achieved with respect to $S$. aureus strain by insertion of the LUMO-HOMO energy gap $\left(\Delta \mathrm{E}_{\mathrm{L}-\mathrm{H}}\right)$ as an additional descriptor to $\mathrm{E}_{\text {LUMO }}$ (Eq. (3); $R=0.791$, $F=10.84$ ), while a poor expression was obtained towards $E$. coli strain $(R=0.48, F=2.18)$ which was improved excluding NBO derivatives (4 and 5) from the plot (Eq. (4); $R=0.72, F=7.10$ ). These results suggest that the electrophilic character of nitroaromatics may contribute to their activity, and the toxic effects of the compounds tend to increase with a decrease in their LUMO-HOMO gap, implying that the softer compounds may be 
Table 2. The minimum inhibitory concentration (MIC) values and activity in terms of -log MIC (pMIC) values of nitroaromatic compounds against Staphylococcus aureus and Escherichia coli strains

\begin{tabular}{|c|c|c|c|c|c|}
\hline \multirow{2}{*}{ No. } & \multirow{2}{*}{ Compound } & \multicolumn{2}{|c|}{ S. aureus (ATCC 25923) } & \multicolumn{2}{|c|}{ E. coli (ATCC 25922) } \\
\hline & & $\mu \mathrm{g} / \mathrm{mL}(\mu \mathrm{M})$ & pMIC & $\mu \mathrm{g} / \mathrm{mL}(\mu \mathrm{M})$ & pMIC \\
\hline 1 & 1,3,5,8-Tetranitro- $9 \mathrm{H}$-carbazole & $1.0(2.9)$ & -0.46 & $4.0(11.5)$ & -1.06 \\
\hline 2 & $\begin{array}{l}\text { 2,4,6-Trinitrophenyl-N-methyl- } \\
\text { nitramine }\end{array}$ & $8.0(27.9)$ & -1.45 & $16.0(55.7)$ & -1.26 \\
\hline 3 & 3,6-Dinitro-9H-carbazole & $128.0(497.7)$ & -2.70 & $128.0(497.7)$ & -2.70 \\
\hline 4 & 4,5,6-TriNBO & $128.0(475.7)$ & -2.68 & $512.0(1902.7)$ & -3.28 \\
\hline 5 & 4,5,6,7-TNBO & $64.0(203.8)$ & -2.41 & $254.0(808.7)$ & -2.91 \\
\hline 6 & 2,4,6-Trinitrotoluene & $64.0(281.8)$ & -2.45 & $16.0(70.4)$ & -1.85 \\
\hline 7 & 3,4-Dinitrotoluene & $128.0(702.9)$ & -2.85 & $256.0(1405.8)$ & -3.15 \\
\hline 8 & 1,4-Dinitrobenzene & $32.0(190.5)$ & -2.28 & $8.0(47.6)$ & -1.68 \\
\hline 9 & 1,2-Dinitrobenzene & $256.0(1524.0)$ & -3.18 & $32.0(190.4)$ & -2.28 \\
\hline 10 & 2-Nitrobenzonitrile & $64.0(432.1)$ & -2.64 & $4.0(27.0)$ & -1.43 \\
\hline 11 & 4-Nitrobenzonitrile & $64.0(432.1)$ & -2.59 & $512.0(3162.4)$ & -3.50 \\
\hline 12 & 4-Nitrobenzaldehyde & $128.0(847.7)$ & -2.93 & $64.0(423.6)$ & -2.63 \\
\hline 13 & 1,3-Dinitrobenzene & $64.0(380.7)$ & -2.58 & $64.0(380.7)$ & -2.58 \\
\hline 14 & 4-Nitroacetophenone & $1024.0(6200)$ & -3.79 & $128.0(775.1)$ & -2.89 \\
\hline 15 & 4-Nitrobenzyl alcohol & $512.0(3735)$ & -3.52 & $512.0(3735)$ & -3.52 \\
\hline 16 & Nitrobenzene & $1024.0(4382)$ & -3.92 & $1024.0(4382)$ & -3.92 \\
\hline 17 & 3-Nitro-1,2,4-triazole & $32.0(211.8)$ & -2.33 & $128.0(847.1)$ & -2.93 \\
\hline 18 & 4(5)-Nitro-imidazole & $64.0(565.9)$ & -2.75 & $16.0(141.5)$ & -2.15 \\
\hline
\end{tabular}

more susceptible to conversion to the reductive intermediates that may cause the impairment of cell functions:

$$
\begin{aligned}
& \mathrm{pMIC}=-3.14( \pm 2.30)-1.26( \pm 0.33) \mathrm{E}_{\mathrm{LUMO}}- \\
& -0.71( \pm 0.32) \Delta \mathrm{E}_{\mathrm{L}-\mathrm{H}^{\prime}} \\
& \mathrm{pMIC}=-4.72( \pm 2.78)-1.31( \pm 0.41) \mathrm{E}_{\mathrm{LUMO}}- \\
& -0.37( \pm 0.34) \Delta \mathrm{E}_{\mathrm{L}-\mathrm{H}^{\circ}}
\end{aligned}
$$

The toxic activity of NACs against $S$. aureus tended to increase with an increase in their molecular weight, MW $(R=0.710, F(1.16)=16.00)$ or van der Waals volume, VdWvol $(R=0.70$, $F=12.70)$, and it tentatively increased with an increase in PSA values $(R=0.68, F=13.30)$ and in the number of hydrogen-bond acceptors $(R=0.70$, $F=13.60)$. Satisfactory expressions were obtained for the activity of NACs against $S$. aureus strain versus $\mathrm{E}_{\mathrm{LUMO}}$ in combination with the molecular weight (Eq. (5); $R=0.81, F=13.02$ ) or van der
Waals volume (Eq. (6); $R=0.79, F=11.96$ ), excluding TNBO (compound 5) from the plots:

$$
\begin{aligned}
& \text { pMIC }=-6.27( \pm 0.85)-0.78( \pm 0.34) \mathrm{E}_{\mathrm{LUMO}}+ \\
& +0.006( \pm 0.002) \mathrm{Mw}, \\
& \text { pMIC }=-6.91( \pm 0.83)-0.95( \pm 0.31) \mathrm{E}_{\mathrm{LUMO}}+ \\
& +0.008( \pm 0.004) \mathrm{VdWvol} .
\end{aligned}
$$

Meanwhile, the pMICs of NACs against E. coli did not show reliable links with these descriptors applied as sole or additional indices to the electrophilic potency of the compounds (data not shown). These might partially be due to the cell envelope structure of Gram-negative bacteria which is more complex than that of Gram-positive bacteria strains: the cell envelope of Gram-negative bacteria strains is composed of a peptidoglycan layer adjacent to a cytoplasmic membrane and an outer membrane $(\mathrm{OM})$ which may serve as a selective permeation barrier for xenobiotic agents, whereas 


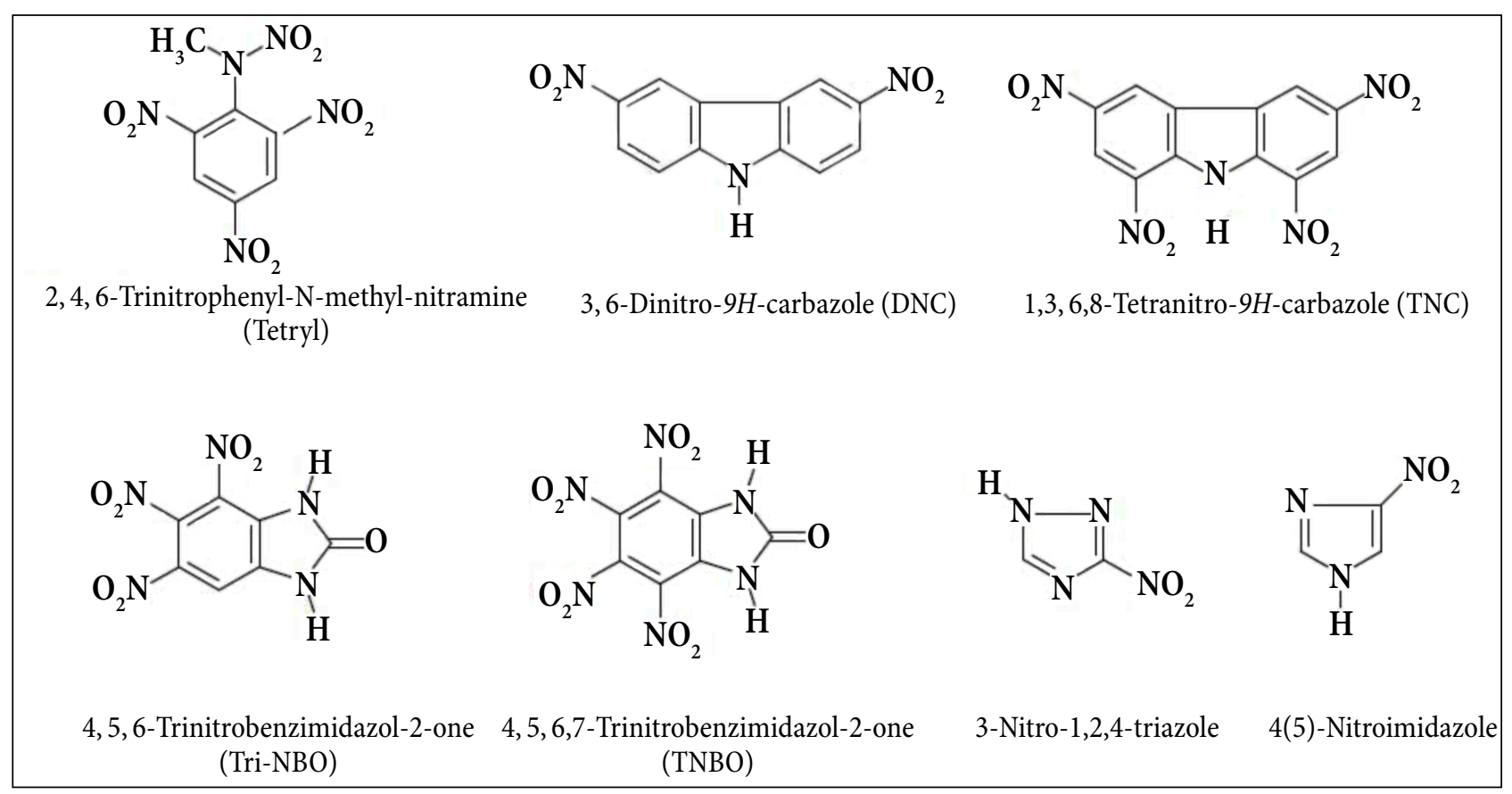

Fig. 1. The structural formulae of nitroaromatics used in the present work

Gram-positive bacteria strains including $S$. aureus lack an OM ([41-42], and refs. therein).

No reliable contribution of the lipophilic factor of nitroaromatics was found against both bacteria strains used in this work (data not shown).

Finally, the pMIC values of nitroaromatics showed a parabolic dependence upon the highest positive values of the electrostatic potentials of the compounds $\left(V_{S, \max }\right)$ against both bacteria strains, with an initial rise and then a fall in the pMIC values with an increase in $V_{S, \max }$
(Fig. 2a, b) which might be associated with a nonspecific (largely electrostatic) interaction of the compounds with the surfaces of the negatively charged bacteria envelopes; the highly negatively charged nature of lypopolysaccharides (LPS) of the outer leaflet of the Gram-negative strains including $E$. coli confers an overall negative cell envelope, whereas the negatively charged teichoic acids (cell surface glycopolymers) are the major constituents of Gram-positive bacteria strains including $S$. aureus [43-45]. Applying $V_{S, \max }$ along

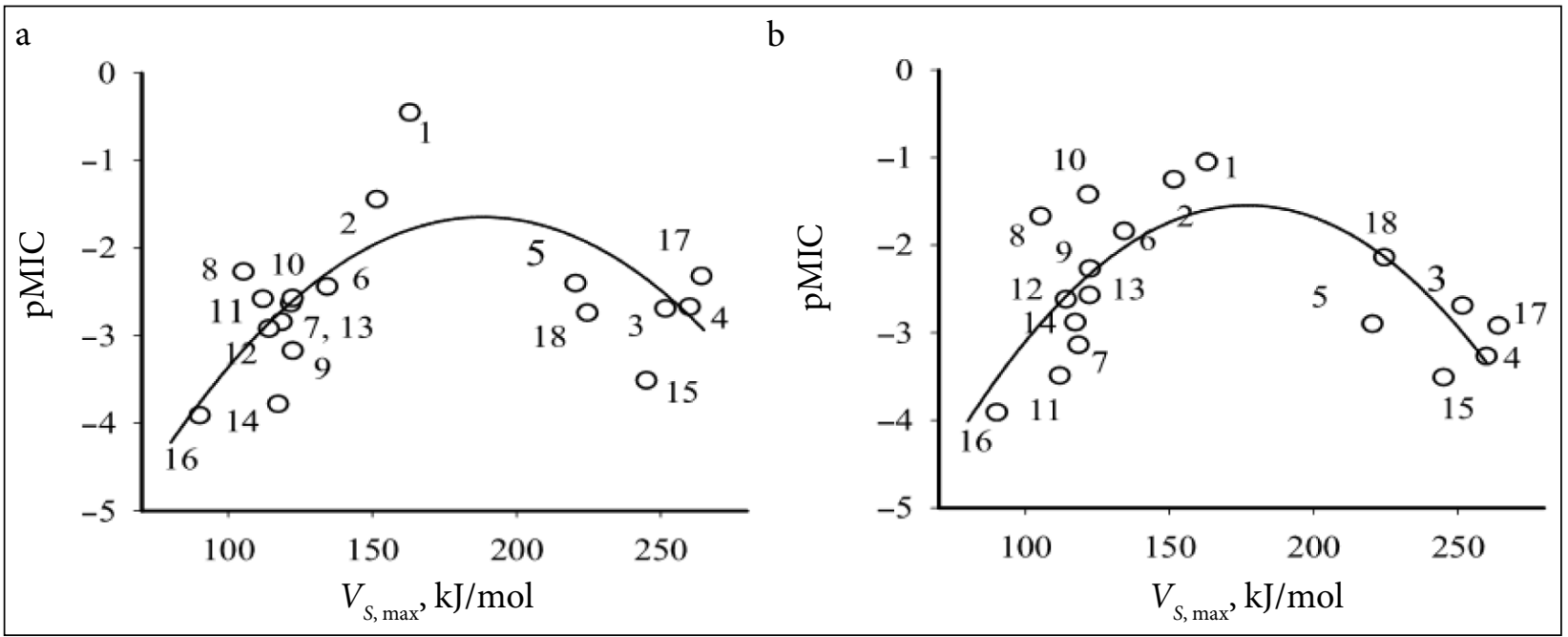

Fig. 2. The activity of nitroaromatics against $S$. aureus (a) and $E$. coli (b) strains versus the highest positive values of MEPs $\left(V_{S \text {, max }}\right)$ at the electron density of 0.001 a.u. The numbers of the compounds are the same as given in Tables 1 or 2 
with the LUMO energy of NACs, the satisfactory QSAR expressions were obtained against $S$. aureus (Eq. (7); $R=0.84$ and $F=9.30)$ and E. coli (Eq. (8); $R=0.81$ and $F=8.70$ ):

$$
\begin{aligned}
& \mathrm{pMIC}=-10.53( \pm 2.14)-0.60( \pm 0.30) \mathrm{E}_{\mathrm{LUMO}}+ \\
& +0.06( \pm 0.02) V_{s, \max }-1( \pm 0.5) \times 10^{-4}\left(\mathrm{~V}_{S, \max }\right)^{2},(7) \\
& \mathrm{pMIC}=-11.69( \pm 2.04)-0.76( \pm 0.36) \mathrm{E}_{\mathrm{LUMO}}+ \\
& +0.09( \pm 0.03) V_{S, \max }-2( \pm 0.7) \times 10^{-4}\left(V_{S, \max }\right)^{2} .(8)
\end{aligned}
$$

\section{CONCLUSIONS}

In this work, the toxic effects of a series of diverse structure nitroaromatics were estimated against Gram-positive Staphylococcus aureus and Gramnegative Escherichia coli bacteria in vitro, and QSAR studies were performed applying a set of molecular descriptors of the compounds assessed by means of quantum mechanical computation. The electrophilic character of nitroaromatics was observed to be an important determinant of their toxic effects. The pMICs of nitroaromatics towards $S$. aureus showed a clear tendency to increase with an increase in their molecular weight and volume, polar surface area and the number of hydrogen bond-acceptors, while these indices did not reveal reliable links with the toxic effects of NACs on E. coli, indicating its sensitivity to structural peculiarities of the compounds which might partly be due to the more complex structure of its cell envelope compared to that of $S$. aureus strain. The activity of the compounds showed a parabolic type dependence on the positive values of molecular surface electrostatic potentials $\left(V_{S, \max }\right)$. This could be associated with the non-specific (electrostatic) interaction of nitroaromatics with the negatively charged bacteria envelope at the initial stage of their action. This study suggests that the molecular indices of the nitroaromatics used in this work might be applied for tentative prediction of their toxic effects on $S$. aureus strain.

\section{ACKNOWLEDGEMENTS}

The authors thank Dr. Elena Bakiene (Department of Biochemistry and Molecular Biology, Life Sciences Center, Vilnius University) for technical assistance in microbiological experiments and helpful discussions. We acknowledge the support of the European Social Fund (Measure No. 09.33-LMT-K-712, Grant No. DOTSUT-34 (09.3.3-LMT-K712-01-0058/LSS-600000-58).

Received 11 December 2018 Accepted 19 December 2018

\section{References}

1. J. C. Spain, Annu. Rev. Microbiol., 49, 523 (1995).

2. C. M. Perez, S. M. Agathos, Biotechnol. Annu. Rev., 6, 197 (2000).

3. R. S. Padda, C. Wang, J. B. Hughes, R. Kutty, G. N. Bennet, Environ. Toxicol. Chem., 22, 2293 (2003).

4. K.-S. Ju, R. E. Parales, Microbiol. Mol. Biol. Rev. 74, 250 (2010).

5. N. Čènas, Ž. Anusevičius, D. Bironaitè, G. I. Bachmanova, A. I. Archakov, K. Ollinger, Arch. Biochem. Biophys., 315, 400 (1994).

6. M. D. Roldan, E. Perez-Reinado, F. Castillo, C. Moreno-Vivian, FEMS Microbiol. Rev., 32, 474 (2008).

7. R. J. Knox, F. Friedlos, M. P. Boland, Cancer Metast. Rev., 12, 195 (1993).

8. Ž. Anusevičius, J. Šarlauskas, N. Čènas, Arch. Biochem. Biophys., 404, 254 (2002).

9. O. Ueda, S. Kitamura, K. Ohashi, K. Sugihara, S. Ohta, Drug Metab. Dispos., 31, 367 (2003).

10. B. Valiauga, E. M. Williams, D. F. Ackerley, N. Čènas, Arch. Biochem. Biophys., 614, 14 (2017).

11. P. J. O’Brien, W. C. Wang, J. Silva, S. Khan, Xenobiotica, 20, 945 (1990).

12. A. Nemeikaitè-Čènienè, V. Miliukienè, J. Šarlauskas, E. Maldutis, N. Čènas, Chemija, 17, 34 (2006).

13. A. Gooch, N. Sizochenko, L. Sviatenko, L. Gorb, J. Leszczynski, SAR QSAR Environ. Res., 28, 133 (2017).

14. J. W. Deneer, T. L. Sinnige, W. Seinen, J. L. M. Hermens, Aquat. Toxicol., 10, 115 (1987).

15. J. W. V. Deneer, C. J. Leeuwen, W. Seinen, J. L. MaasDiepeveen, J. L. M. Hermens, Aquat. Toxicol., 15, 83 (1989).

16. M. T. D. Cronin, B. W. Gregory, T. W. Schultz, Chem. Res. Toxicol., 11, 902 (1998).

17. O. Isayav, B. Rasulev, L. Gorb, J. Leszczynski, Molec. Diversity, 10, 233 (2006).

18. K. Dieguez-Santana, H. Pharm-The, P. J. VillegasAguilar, H. Le-Thi-Thu, J. A. Castilo-Garit, G. M. Casanola-Martin, Chemosphere, 165, 434 (2016).

19. M. Klein, H. Voightman, T. Haak, L. Erdinger, G. Boche, Mutat. Res./Genetic Toxicol. Environ. Mutagen., 467, 55 (2000).

20. M. Klein, L. Erdinger, G. Boche, Mutat. Res., 467, 69 (2000). 
21. C. E. Clarkson, I. G. Holden, T. Malkin, J. Chem. Soc., 0, 1556 (1950).

22. J. Zhao, L. Peng, Y.-L. Zhu, et al., Polymer, 91, 118 (2016).

23. F. A. Neugebauer, H. Fischer, Chem. Ber., 105, 2686 (1972).

24. H. Schindlbauer, W. Kwiecinski, Monatsh. Chem., 107, 1307 (1976).

25. J. Šarlauskas, E. Dičkancaite, A. Nemeikaitè, et al., Arch. Biochem. Biophys., 346, 219 (1997).

26. H. Xue, H. Gao, B. Twamley, J. M. Shreeve, Chem. Mater., 19, 1731, (2007).

27. M. Bahnous, A. Bouraiou, M. Chelghoum, Bioorg. Med. Chem. Lett., 23, 1274 (2013).

28. M07-A8: 2009, Methods for Dilution Antimicrobial Susceptibility Tests for Bacteria That Grow Aerobically; Approved Standard - Eighth Edition.

29. R. F. W. Bader, M. T. Carrol, R. J. Cheeseman, C. Chang, J. Am. Chem. Soc., 109, 7968 (1987).

30. F. A. Bulat, A. Toro-Labbe, T. Brink, J. S. Murray, P. Politzer, J. Mol. Model., 16, 1679 (2010).

31. J. Šarlauskas, L. Misevičienè, A. Marozienè, et al., Int. J. Mol. Sci., 15, 23307 (2014).

32. K. G. Von Eschwege, J. Conradie, S. Afr. J. Chem., 64, 203 (2011).

33. M. Karelson, V. S. Lobanov, Chem. Rev., 96, 1027 (1996).

34. R. G. Pearson, J. Chem. Sci., 117, 369 (2005).

35. D. E. Clark, J. Parm. Sci., 88, 807 (1999).

36. P. Politzer, P. R. Laurence, K. Jayasuriya, Environ. Health Perspect., 61, 191 (1985).

37. P. C. Mishra, A. Kumar, Molecular Electrostatic Potentials: Concepts and Applications, eds. J. S. Murray and K. D. Sen, Elsevier (1996).

39. P. Politzer, J. S. Murray, Z. Peralta-Inga, Int. J. Quant. Chem., 85, 676 (2001).

40. P. Politzer, J. S. Murray, M. C. Concha, Int. J. Quant. Chem., 88, 19 (2002).

41. H. Nikaido, Mikrobiol. Molec. Biol. Rev., 67(4), 593 (2003).

42. J. C. Lopez-Romero, H. Gonzalez-Rios, A. Borges, M. Simoes, Evid. Based Complement. Alternat. Med. 2015, ID 795435 (2015).

43. T. J. Silhavy, D. Kohne, S. Walker, Cold Spring Harb. Perspect. Biol., 2, a000414 (2010).

44. J. G. Svoboda, J. Campbell, T. C. Meredith, S. Walker, ChemBioChem., 11, 35 (2010).

45. S. Brown, J. S. Santa Maria Jr., S. Walker, Annu. Rev. Microbiol., 67, 313 (2013).
Jonas Šarlauskas, Evelina Polmickaitė-Smirnova, Narimantas Čènas, Kastis Krikštopaitis, Žilvinas Anusevičius

\section{NITROAROMATINIŲ JUNGINIŲ ANTIBAKTERINIO AKTYVUMO KIEKYBINIŲ STRUKTŪROS AKTYVUMO RYŠIŲ TYRIMAI}

Santrauka

Darbe tirti nitrobenzeno ir nitroheterociklinių junginių aktyvumai prieš Staphylococcus aureus (ATCC 25923) ir Escherichia coli (ATCC 25922) bakterijas bei nustatyti junginių aktyvumo ir jų elektroninių, struktūros ir kitų molekulinių deskriptorių galimi kiekybiniai struktūrosaktyvumo ryšiai. 